\title{
Evaluation of Spermatogenic Activity of Annona muricata Methanolic Bark Extract in Albino Rats
}

\author{
T.A. Oladipo ", A.A. Adebiyi ${ }^{* *}$, A. S Adetomiwa ${ }^{* * * *}$, O. O Oladipo ${ }^{* * * * *}$, O.E. \\ Adeleye $^{* * * *}$, and J.O. Olukunle ${ }^{* * *}$ \\ * Federal College of Animal Health and Production, Technology, Moor Plantation, \\ Ibadan ${ }^{* *}$ Department of Veterinary Pathology, Federal University of Agriculture, \\ Abeokuta, Nigeria ${ }^{* * *}$ Federal University of Agriculture, Abeokuta, Department of \\ Veterinary Physiology and Pharmacology, ${ }^{* * * *}$ Federal University of Agriculture, \\ Abeokuta, Department of Veterinary Public Health and Reproduction and ${ }^{* * * * *}$ Federal \\ College of Agriculture, Ibadan, Department of Agricultural Engineering, Nigeria.
} Background: Annona muricata has been widely used by majority of people in the treatment
of this plant, it is important to study its effect on semen factors that determines reproductive health.

\begin{abstract}
Materials and method: Sixteen male rats weighing 150-200g were given Annona muricata methanolic bark extract (AMMBE) for fourteen days at the dose rate of $0 \mathrm{mg} \mathrm{kg}^{-1}, 200 \mathrm{mgkg}^{-1}$, $400 \mathrm{mgkg}^{-1}$ and $800 \mathrm{mgkg}^{-1}$ representing groups A, B, C and D respectively. The sperm cells were analyzed to determine the sperm counts, morphological appearances and survivability. Testes were also fixed in formalin for histopathology. The results obtained were analyzed using standard statistical package.

Results: The results showed that the sperm liveability of rats treated with Annona muricata methanolic bark extract (AMMBE) were statistically significantly lower in groups B, C and D having mean values of $78.50 \pm 1.62,86.50 \pm 3.11$ and $68.00 \pm 1.96$ respectively while the control group had $91.00 \pm 2.86$, sperm motility was found to be highest in control group with $93.50 \pm 3.22$ while other groups $(B, C$ and $D)$ had $82.25 \pm 2.20,87.50 \pm 1.96$ and $71.25 \pm 2.34$ respectively. This finding showed strong correlation between the sperm motility and live-death ratio. In addition, there was reduction in the sperm concentration in a dose dependent manner, while the testicular histology revealed lesions that indicate potential for structural damages.
\end{abstract}

Conclusion: It was concluded that due to the reductions in sperm motility, sperm concentration and live-death ratio, Annona muricata prolonged use may be detrimental.

Keywords: Annona muricata, albino rats, methanol, sperm, motility, survivability

\section{Introduction}

Ethno-medicine uses numerous plants, one of which is Annona muricata, which is commonly called soursop in most part of Nigeria. The plant has a large and rich history of usage in human beings [1]. The first people who knew about this plant species were undoubtedly the several Amerindian ethnic groups who lived in Central and South America [1]. The first use attributed to this plant was probably as food, but over the years a series of curative properties were gradually discovered and transmitted from generation to generation by the different native people of the several regions in America [2].
Annona muricata is employed in the treatments of variety of diseases ranging from arthritic pains, asthma, bronchitis, catarrh, colic, cough, diabetes, dysentery, oedema, fever, gallbladder disorder, hypertension, liver disorders, malaria, nervousness, neuralgia, palpitation, parturition, rashes, rheumatism, ringworm, skin disorders, spasms, tumors and ulcers $[3,4,5]$. Scientific investigations have substantiated its use as hypoglycemic, anticancer and antidiabetic agent [6].

Despite its medicinal uses, the plant has a very important compound called Annonacin which 
could lead to differenthealth conditions. Annonacin has been confirmed to be a potent neurotoxin associated with neurodegenerative disease and has also been reported to cause cell death [7]. The possible effects of the plant extract on sperm cell morphology and qualities needed to be documented because of it importance of reproductive health

\section{Materials and Methods}

Fresh back of Annona Muricata (soursop) was collected from within the vicinity Federal College of Agriculture, Ibadan and chopped into smaller pieces before it was sundried. Small sample of freshly harvested Annona muricata back was taken to the Herbarium, Department of Botany, University of Ibadan, for identification of species. The sundried Annona muricata bark were ground into powder five hundred grams $(500 \mathrm{~g})$ of (AMMBE) was soaked into 2 liters of methanol and left for 72 hours. The solution was squeezed and filtered with a muslin cloth and the filtrate was poured into conical flask to be concentrated on water bath at $40^{\circ} \mathrm{C}$ until semi-solid extract was gotten with a yield of $29 \mathrm{~g}$, and then dissolved in DMSO (Dimethyl Sulfoxide) before diluted into $100 \mathrm{ml}$ distilled water to $290 \mathrm{mg} / \mathrm{ml}$ concentration. The methanol (AMMBE) extract was stored in a refrigerator prior use.

Sixteen apparently healthy male Albino rats weighing $150-200 \mathrm{~g}$ body weight were purchased from Research Animal World Laboratory (Rawlab), Physiology Department, University of Ibadan. The animals were acclimatized for 7 days and fed on rat chow. The experiment was conducted at the Animal House of the Federal College of Animal Health and Production Technology, Moor Plantation, Ibadan and this experiment lasted for 14 days.

Experimental design

The experiment was allotted into four (4) treatment A, B, C and D with four (4) animals per group; all fed on rats' chow, using completely randomized design. Group B, C and D were treated with Annona muricata methanol bark extract (200, 400 and 800) $\mathrm{mgkg}^{-1}$ daily for fourteen (14) days orally.

Group A which served as the control were given distilled water throughout without AMMBE. Group B animals were given 200 mgkg${ }^{1}$ methanolic extract of Annona muricata methanol bark (AMMBE). Group $\mathrm{C}$ was administered with $400 \mathrm{mgkg}^{-1}$ methanolic extract while Group D animals were given $800 \mathrm{mg} / \mathrm{kg}^{-1}$ of the extract for 14 days. The rats were ether anaesthetized, and the testes were harvested, the cauda epididymis was cut open to harvest the matured sperm cells. All experimental protocols carried out on the animals were in accordance with the internationally accepted principles for the laboratory animal usage and were approved by Ethics Committee on the Laboratory Animal Use of the College of Veterinary Medicine of University of Agriculture, Abeokuta.

\section{Procedure for sperm characteristic analysis}

The testes from each rat were carefully exposed and one of them was removed together with its epididymis, the epididymis was separated and the epidydimal fluid was collected from the caudal part. A portion of the sperm harvested from the cauda epididymis were stained with eosin-nigrosin on a glass slide and air-dried. The slides were examined through the aid of a digital microscope under the magnification of $x 40$ and the percentage of survivability of the sperm cells was determined by the number of sperm cells that picked the stain compared to those that did not pick the stain. The percentage motility was taken and abnormalities was observed on each slide and four air-dried smears were prepared on glass slides for each sample of the four groups. The progressive sperm motility, sperm concentration, liveability (viability) and morphology were all determined $[8,9]$.

\section{Testicular histology}

Sample of the rat's testes were prefixed in Bouin-Hollande solution prior to the histologic studies as earlier described [10,11].

\section{Statistical analysis}

The mean and standard error of mean were calculated for all the sperm parameters. Analysis of variance (ANOVA) was used to establish any significant difference in all the stated parameters. A P value less than 0.05 was considered significant in all cases.

\section{Results}

There was a statistically significant $(\mathrm{P}<0.05)$ decrease in the progressive sperm motility and percentage sperm liveability of the male Wistar rats treated with the methanolic extract Annona muricata bark when compared with the control

The result revealed that the sperm liveability of Annona muricata methanol bark extract (AMMBE) treated rat were generally lower in

Egypt. J. Vet. Sci. Vol. 49, No. 2 (2018) 
groups B, C and D having values of $86.50 \pm 3.11$, $78.50 \pm 1.62$ and $68.00 \pm 1.96$ respectively while the control group had $91.00 \pm 2.86$. This showed that the liveability of the sperm reduces with the increase in dosage of Annona muricata methanolic bark extract (AMMBE) (Table 1).

The effect of Annona muricata methanol bark extract (AMMBE) also caused a statistically significant $(\mathrm{P}<0.05)$ reduction in the sperm motility of the animals in groups B, C and D $(87.50 \pm 1.96$, $82.25 \pm 2.20$ and $71.25 \pm 2.34) \%$ respectively when compared with that the percentage motility of the control group $(93.50 \pm 3.22 \%)$, the sperm motility was observed to reduced in a dose dependent manner (Table 2).

The result in table 3 showed the correlation between sperm motility and live-death ratio. The result obtained suggest that there was strong correlation between sperm motility and the sperm live-death ratio, which was statistically significant at $(\mathrm{P}<0.05)$ (Table 3).
In addition, the sperm concentration of the Wistar rats following oral administration of $200 \mathrm{mg} / \mathrm{kg}, 400 \mathrm{mg} / \mathrm{kg}$ and $800 \mathrm{mg} / \mathrm{kg}$ doses of the methanolic extract of $A$. muricata bark was significantly reduced in a dose-dependent manner with $(67.25 \pm 2.56,60.25 \pm 1.75$ and $50.00 \pm 2.02)$ $\left(\mathrm{x} 10^{6}\right)$ as values observed in groups $\mathrm{B}, \mathrm{C}$, and $\mathrm{D}$ respectively when compared with the control value $\left(69.00 \pm 2.44 \times 10^{6}\right)$ (Table 4).

The table revealed that as the dosage of the extract increases, the sperm cell concentration gradually shows reduction that was statistically significant at $(\mathrm{P}<0.05)$ especially at the dosage of $800 \mathrm{mgkg}^{-1}$ (Table 4).

At lower doses 200mgkg-1 and 400mgkg-1, there was significant change in the total number of spermatozoa with morphological abnormalities in the treated groups compared with the control. However, at $800 \mathrm{mgkg}-1$, there were far more significant $(\mathrm{P}<0.05)$ increase in the spermatozoa abnormalities observed when compared with the control group (Table 5).

TABLE 1. Effect of Annona muricata on live-death in albino rats.

\begin{tabular}{cccc}
\hline Groups & $\begin{array}{c}\text { Mean liveability per } \\
\text { group (\%) }\end{array}$ & $\begin{array}{c}\text { Mean sperm } \\
\text { death per group (\%) }\end{array}$ & $\begin{array}{c}\text { Normal values for sperm } \\
\text { liveability (\%) }\end{array}$ \\
\hline A control & $91.00 \pm 2.86^{\mathrm{a}}$ & $9.00 \pm 0.36^{\mathrm{a}}$ & 50 and above \\
B $200 \mathrm{mgkg}^{-1}$ & $86.50 \pm 3.11^{\mathrm{b}}$ & $13.50 \pm 1.56^{\mathrm{b}}$ & \\
C $400 \mathrm{mgkg}^{-1}$ & $78.50 \pm 1.62^{\mathrm{c}}$ & $21.50 \pm 0.91^{\mathrm{c}}$ & \\
D $800 \mathrm{mgkg}^{-1}$ & $68.00 \pm 1.96^{\mathrm{d}}$ & $32.00 \pm 2.42^{\mathrm{d}}$ & \\
\hline
\end{tabular}

Superscript with different alphabets were statistically significant at $\mathrm{P} \leq 0.05$

TABLE 2. Effect of Annona muricata on of sperm cell motility in albino rats.

\begin{tabular}{ccc}
\hline Groups & $\begin{array}{c}\text { Mean sperm motility } \\
\text { per group (\%) }\end{array}$ & Normal value of sperm motility (\%) \\
\hline $\mathrm{A}(\mathrm{Control})$ & $93.50 \pm 3.22^{\mathrm{a}}$ & 60 and above \\
$\mathrm{B}\left(200 \mathrm{mgkg}^{-1}\right)$ & $87.50 \pm 1.96^{\mathrm{b}}$ & \\
$\mathrm{C}\left(400 \mathrm{mgkg}^{-1}\right)$ & $82.25 \pm 2.20^{\mathrm{b}}$ & \\
$\mathrm{D}\left(800 \mathrm{mgkg}^{-1}\right)$ & $71.25 \pm 2.34^{\mathrm{c}}$ & \\
\hline
\end{tabular}

Superscript with different alphabets were statistically significant at $\mathrm{P} \leq 0.05$.

TABLE 3. Correlation between sperm motility and live-dead ratio.

\begin{tabular}{|c|c|c|c|c|}
\hline & & $\begin{array}{c}\text { Number of } \\
\text { rats }\end{array}$ & Pearson Correlation & Sig. (2-tailed) \\
\hline Pair 1 & $\begin{array}{l}\text { Sperm cell motility }(\%) \text { and } \\
\text { Sperm cell live }(\%)\end{array}$ & 16 & 0.508 & .044 \\
\hline Pair 2 & $\begin{array}{l}\text { Sperm cell motility (\%) and } \\
\text { Sperm cell dead (\%) }\end{array}$ & 16 & -0.508 & .044 \\
\hline
\end{tabular}


TABLE 4. Effect of Annona muricata on sperm concentration of albino rats.

\begin{tabular}{ccc}
\hline Groups & Sperm concentration (x106) & $\begin{array}{c}\text { Normal sperm concentration } \\
(\mathbf{x 1 0 6})\end{array}$ \\
\hline $\mathrm{A}(\mathrm{CONTROL})$ & $69.00 \pm 2.4^{4} \mathbf{a}$ & 1.84 \\
$\mathrm{~B} 200 \mathrm{mg} / \mathrm{kg}$ & $67.25 \pm 2.56$ & \\
$\mathrm{C} 400 \mathrm{mg} / \mathrm{kg}$ & $60.25 \pm 1.75$ \\
$\mathrm{D} 800 \mathrm{mg} / \mathrm{kg}$ & $50.00 \pm 2.0^{2} \mathbf{c}$ \\
\hline
\end{tabular}

Superscript with different alphabets were statistically significant at $\mathrm{P} \leq 0.05$

TABLE 5. Morphological appearances of sperm cells.

\begin{tabular}{|c|c|c|}
\hline Groups & $\begin{array}{l}\text { Sperm cell } \\
\text { colour appearances }\end{array}$ & Sperm morphology \\
\hline $\mathrm{A}$ (Control) & $\begin{array}{l}\text { slightly yellowish and slightly } \\
\text { creamy }\end{array}$ & intact sperm cells predominant \\
\hline B $200 \mathrm{mgkg}^{-1}$ & $\begin{array}{l}\text { slightly creamy with few cells } \\
\text { appearing watery }\end{array}$ & intact sperm cells with few having bent tails \\
\hline C $400 \mathrm{mgkg}^{-1}$ & yellowish and slightly creamy & $\begin{array}{l}\text { intact sperm cells with some cells having curved and } \\
\text { bent tails }\end{array}$ \\
\hline D $800 \mathrm{mgkg}^{-1}$ & yellowish and deeply creamy & $\begin{array}{l}\text { intact sperm cells with cells having curved tails, bent } \\
\text { tails and double tails }\end{array}$ \\
\hline
\end{tabular}

N/B- Intact sperm cells (head, midpiece and tail present).

The major morphological abnormalities observed in the group of rats administered with 200mgkg-1 of the extract are bent tails (Fig. 1), whereas in the group dosed with $400 \mathrm{mgkg}-1$ of a. muricata extract expressed semen with both bent tails and curved tails (Fig 2) and the group administered with $800 \mathrm{mgkg}-1$ expressed more of double tails sperm cells (Fig .3).

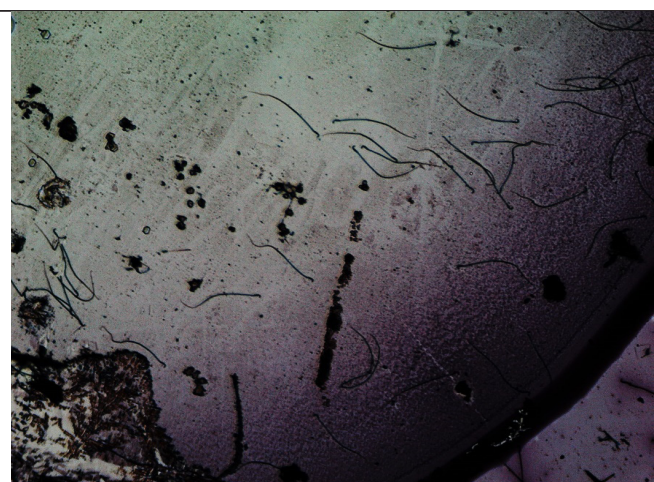

Fig. 1. sperm cells with bent tails (star) observed in group dosed with $200 \mathrm{mgkg}^{-1}$ of A. muricata.
Also, Table 5 shows that the sperm cells colouration improved as the dosage of AMMBE increased, while slight aberrations of the sperm cells were observed at dosage of $200 \mathrm{mgkg}^{-1}$ and above.

Histopathology of the testis of rats administered different doses of extract of AMMBE revealed varying degrees of testicular degeneration and atrophy characterized by moderate variation in sizes of seminiferous tubules (Fig 4, 5 \& 6).

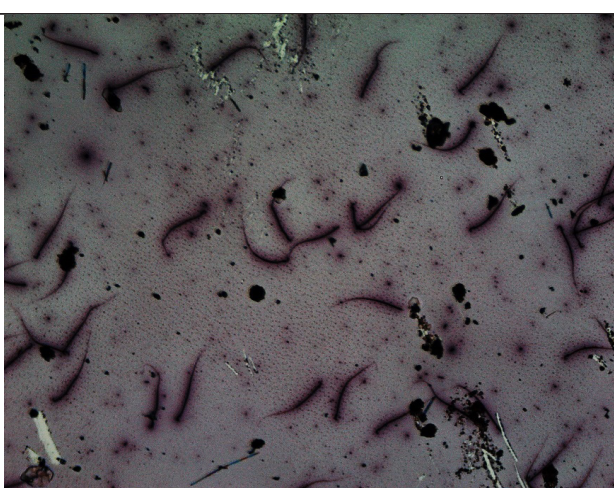

Fig. 2. sperm cells with bent and curved tails (star) observed in group dosed with $400 \mathrm{mgkg}-1$ of A. muricata.

Egypt. J. Vet. Sci. Vol. 49, No. 2 (2018) 


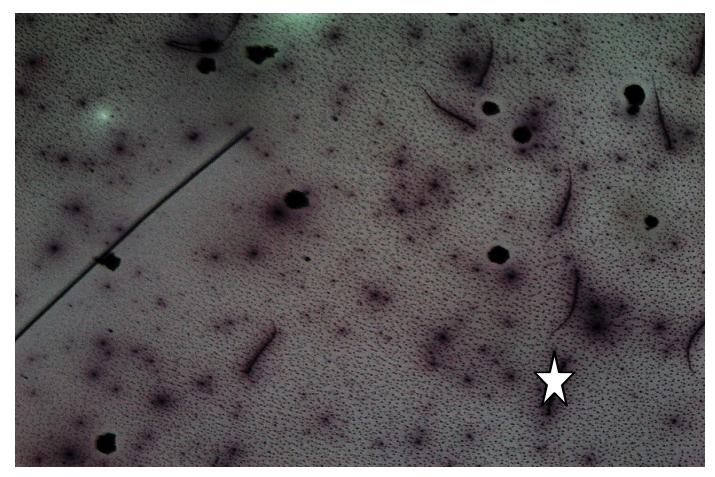

Fig. 3. sperm cells with double tails (star) observed in group dosed with 800 mgkg-1of A. muricata

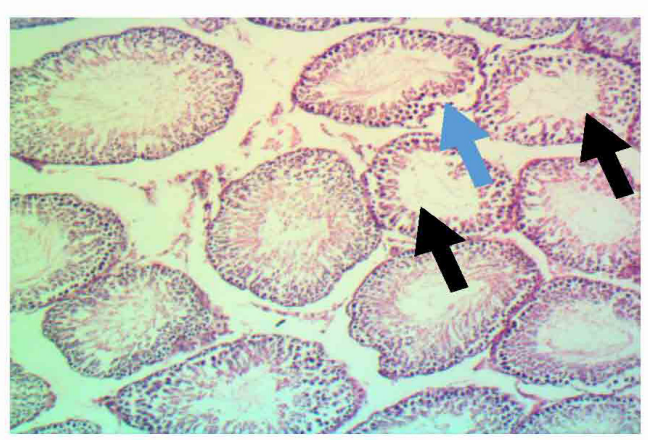

Fig. 5. Testis section showing moderate testicular degeneration and atrophy characterized by moderate variation in sizes of seminiferous tubules, wavy basement membrane (blue arrow), hypocellular seminiferous tubules (arrowed) and distended interstitial spaces. H \&E. X10 (Effects of 800mgkg-1 of Annona muricata)

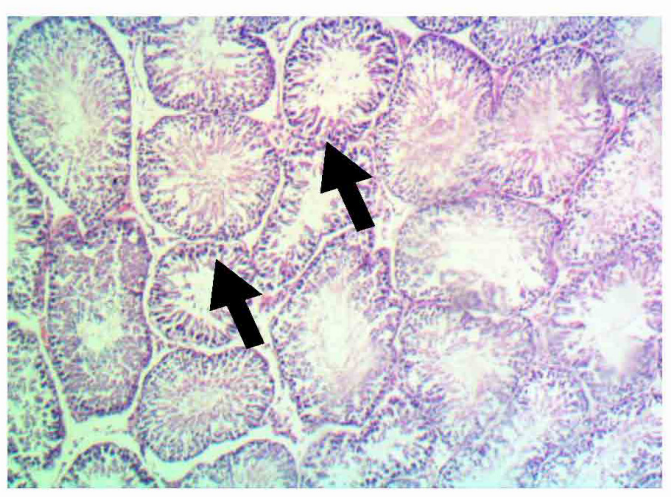

Fig. 4. Testis section showing mild testicular atrophy. Focal, small diameter, hypoplastic seminiferous tubules (arrowed). H \&E. X10 (Effects of 800mgkg-1 of Annona muricata)

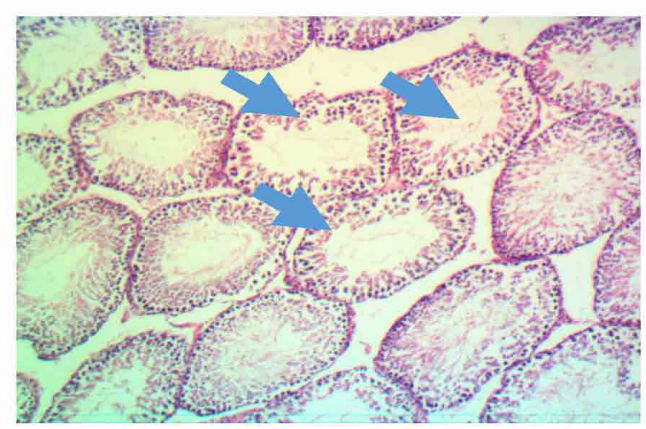

Fig.6. Testis section showing moderate testicular degeneration and atrophy. Focal hypocellular seminiferous tubules (arrowed) with wavy basement membrane and clear wide luminal diameter. Focal widening of the interstitial spaces. $H$ \&E. X10 (Effects of 800mgkg-1 of Annona muricata). 


\section{Discussion}

The administration of (AMMBE) caused a reduction in progressive sperm motility, percentage sperm liveability, sperm concentration, and also increased some secondary morphological sperm abnormalities.

Sperm motility relies on the coordinated propagated flagella wave that is under the influence of acetylcholinesterase [12]. The spermatozoa motility is energy dependent, fueled by fructose and glucose oxidation, so reduction in the progressive sperm motility of the treated rats seen in this study could be due to the acetylcholinesterase inhibition and hypoglycemic properties of the specie of this plant as reported Sovia et al. [13]. The significant decrease in the sperm concentration supported by the various degrees of degeneration in the histologic sections of the testis, suggests that Annona muricata methanolic bark extract is capable of permeating the blood-testis barrier [14].

Despite the reduction in the sperm concentration due to the effect of Annona muricata, the sperm concentration in this study was still found to be above the recommended level. Notwithstanding, care must be taken when using the extract beyond the 14days duration and when given the extract at higher doses than 800 mgkg- ${ }^{1}$, because the reduction has been seen to be dose dependent. The result obtained in this study is in contradiction with the finding of Obembe et al.[15], who found that sperm concentration increases with dosage in Wistar rats exposed to Moringa oleifera, but the outcome of our study aligned with Awodele et al. [16] who reported significant reduction in sperm count when rats were administered with Moringa oleifera.

It was also noted that despite the reduction in the value of sperm liveability observed, the average percentage liveability across the groups were generally higher than the standard recommended value, which shows that AMMBE when used within at a dose of $800 \mathrm{mgkg}-1$ and below for few days has negligible deleterious effect on sperm liveability, this outcome also appears to contradict the work of Ekaluo et al. [17], who reported that soursop fruit extract mitigated the effect of caffeine toxicity on sperm cells.

Egypt. J. Vet. Sci. Vol. 49, No. 2 (2018)
The various semen morphological abnormality like bent tail, curved tail and double tail, observed in this study is in consonance with the work of Saba et al. [18] which reported that the extract of Lagernaria brevifolia caused morphological alterations of sperm cells with predominantly secondary abnormality that includes: bent midpiece, curved mid-piece, bent tail, curved tail, normal tail without head, normal head without tail, looped tail, and coiled tail, which are indications of interference with maturation stage of spermatogenesis in the seminiferous tubules and the histopathology also depicts tendency towards anti-spermatogenic potential.

In conclusion, this study shows that daily oral administration of $200-800 \mathrm{mgkg}^{-1}$ body weight of Annona muricata methanolic bark extract for a period of 14 days has mild anti-spermatogenic effects on adult male Wistar rats and suggest that caution should be applied when using this extract at higher doses or for a longer duration

\section{References}

1. Santos, A.F. Molluscicidal properties of some species of Annona. Phytomed, 8 (2) 115-720(2001).

2. Schulte, R.E. and Raffaur, R. The healing forest: Medicinal and Toxic Plants of the Northwest, Amazon Portland R.F., Dioscorrides press.1999.

3. Shahidi F, Chavan UD, Bal AK and Mckenzie DB. Chemical composition of beach pea plant parts. Food Chem., 64, 39-44 (1999).

4. Moghadamtousi, S.Z., Fadaeinasab, M., Nikzad, S., Mohan, G., Ali, H.M. and Kadir, H.A. 2015. Annona muricata (Annonaceae): A Review of Its Traditional Uses, Isolated Acetogenins and Biological Activities. See comment in PubMed Commons below Int J Mol Sci., 16 (7),1562515658(2015). doi: 10.3390/ijms160715625.

5. Florence, N.T., Benoit, M.Z., Jonas, K., Alexandra, T., Désiré, D.D., Pierre, K. and Théophile, D. Antidiabetic and antioxidant effects of Annona muricata (Annonaceae), aqueous extract on streptozotocin-induced diabetic rats. J. Ethnopharmacol, 151 (2), 784-90. (2014) doi: 10.1016/j.jep.2013.09.021. Epub 2013 Sep 25.

6. Degnon, R.G., Adjou, E.S., Noudogbessi, J.P., Metome, G., Boko, F., Dahouenon-Ahoussi, E., Soumanou, M. and Sohounhloue, D.C. Investigation on nutritional potential of soursoup (AnnonamuricataL.) for its use as food supplement against protein deficiency. Inter. $J$. Biosci., 3 (6), 135-144 (2013). 
7. Lannuzel, A., Michel, P.P., Hoglinger, G.U., Champy, P., Jousset, A., Medja, F. et al. The mitochondrial complex I inhibitor annonacin is toxic to mesencephalic dopaminer-gic neurons by impairment of energy metabolism. Neurosci, 121, 287-296(2003).

8. World Health Organization. WHO Laboratory Manual for Examination of Human Semen and Semen-Cervical Mucus Interaction, $2^{\text {nd }}$ ed., London: Cambridge University Press, (1987) p. 1-10.

9. Blom E. The ultrastructure of some characteristic sperm defects and a proposal for a new classification of the bull spermiogram. Mord. Vet. Med., 25, 283285(1973).

10. Raji, Y, Udoh, US, Mewoyeka, OO, Ononye, FC and Bolarinwa, AF. Implication of reproductive endocrine malfunction in male antifertility efficacy of Azadirachta indica extract in rats. Afr. J. Med. Sci., 32, 159-165 (2003).

11. Akpantah, A.O., Oremosu, A.A., Ajala, M.O., Noronha, C.C., Okanlawon, A.O. The effects of crude extract of Garcinia kola seed on the histology and hormonal milieu of male Sprague- Dawley rats' reproductive organs. Nig. J. Health \& Biomed. Sci., 2, 40-46 (2003).

12. Nelson, L. Quantitative evaluation of sperm motility control mechanisms. Biol. Reprod., 6, 319-324 (1972).

13. Sovia, E., Ratwita, W., Wijayanti, D., Novianty, D.R. Hypoglycemic and hypolipidemic effects of Annona muricata 1. leaf ethanol extract. Intern $J$ Pharm and Pharmaceut Sci, 9 (3), 170-174 (2017).
14. Li, M.W., Xia, W., Mruk, D.D., Wang, C.Q., Yan, H.H., Siu, M.K., Lui, W.Y., Lee, W.M., Cheng, C.Y. Tumor necrosis factor- $\alpha$ reversibly disrupts the blood-testis barrier and impairs Sertoli-germ cell adhesion in the seminiferous epithelium of adult rat testes. J. Endocrinol., 190, 313-329 (2006).

15. Obembe AO, Urom SE, Ofutet EO Ikpi DE, Okpo-Ene AI. The effect of aqueous seed extract of Moringa Oleifera on sperm count, motility and morphology in male Albino Wistar rats. Der Pharmacia Lettre, 7 (3),129-133(2015).

16. Awodele, I.A., Oreagba, S. Odoma, J.A., da Silva, V.O., Osunkalu. J ethnopharmacol, 139 (2), 330336(2012).

17. Ekaluo, U.B., Ikpeme, E.V., Ibiang, Y.B. and Omordia, F.O. Effect of Soursop (Annona muricata L.) Fruit Extract on Sperm Toxicity Induced by Caffeine in Albino Rats. J. Med. Sci., 13, 6771(2013).

18. Saba, Adebowale Bernard Olayinka Ayotunde Oridupa, Matthew Olugbenga Oyeyemi and Oluwaseun Dapo Osanyigbe, Spermatozoa morphology and characteristics of male wistar rats administered with ethanolic extract of Lagenaria Breviflora Roberts African Journal of Biotechnology, 8 (7), 1170-1175(2009).

(Received 05/02/2018; accepted 08/07/2018) 


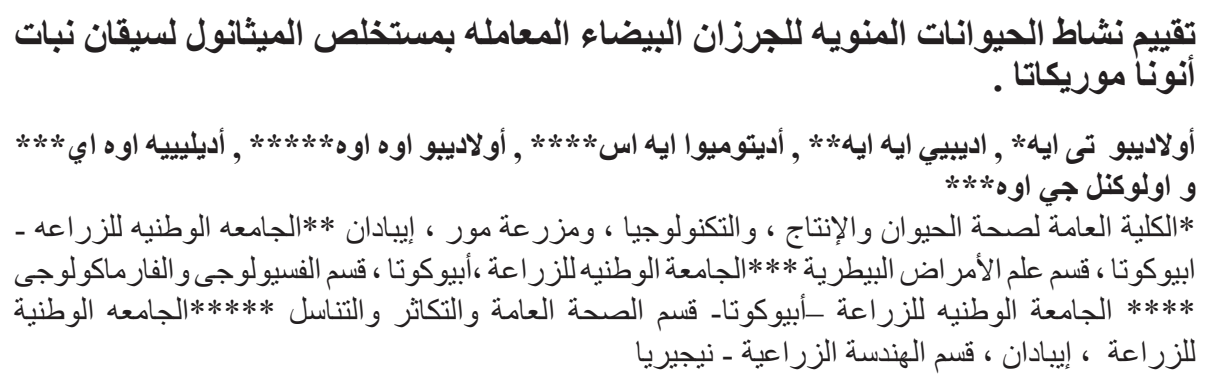

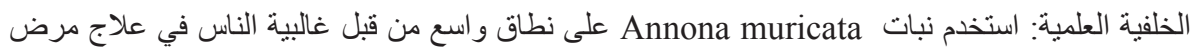

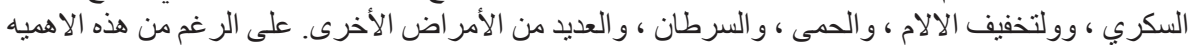

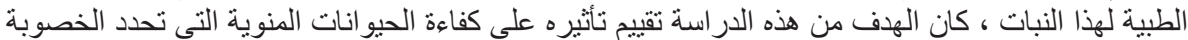
فى الحيو انات .

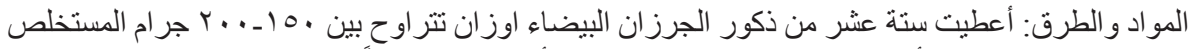

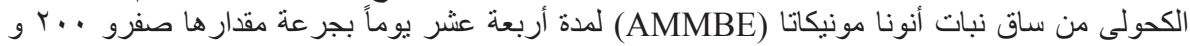

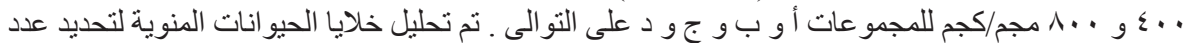

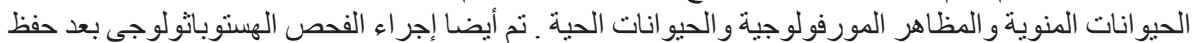
الاعضاء التناسلية فى الفورمالين ـ تم تحليل النتائج التي تم الحصول علية النيها باستخدام الحزمة الإحصائية القياسية.

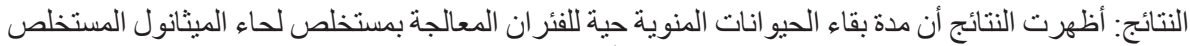

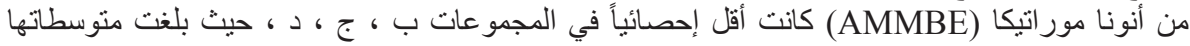

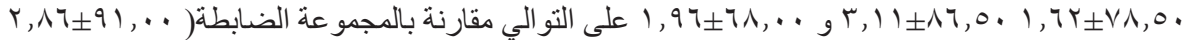

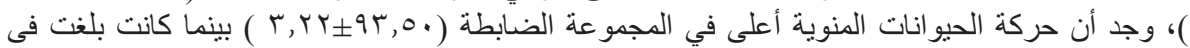

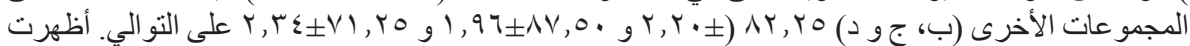

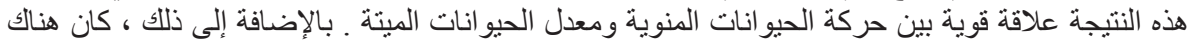

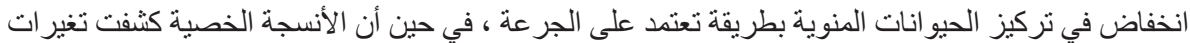

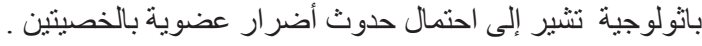

الخلاصة: خلص إلى أنه نتيجة لانخفاض حركة الحيو انات المنوية ، وتركيز الحيو انات المنوية ونسبة الوفاة الحية

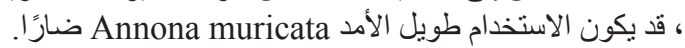
الكلمات الرئيسية: أنونا موريكاتا ، جرذان البيضاء ، ميثانول ، حيو انات منوية ، حركية ، قابلية البقاء 